\title{
Resepsi Remaja terhadap Konten@BotakTikTok di Media Sosial TikTok
}

\author{
Steven Kesuma, H.H. Daniel Tamburian \\ steven.915170011@stu.untar.ac.id, danielt@fikom.untar.ac.id
}

Fakultas Ilmu Komunikasi Universitas Tarumanagara

\begin{abstract}
TikTok is an application that gives users access to create short videos with their creations and creativity. In the TikTok application, there are lots of content creators who create content - content ranging from positive content to negative content. The author focuses more on@BotakTikTok creator content because this creator's content is unique, namely having 3 TikTok accounts. The purpose of this study is to describe the reception of adolescents to the content of@BotakTikTok on social media. The research method used in this research is a qualitative approach with phenomenological research. Phenomenological research is used by the author because it allows to find out and understand about the meaning of content in social media (TikTok). The results of the data were obtained through direct interviews with 3 sources, direct observation and literature study. Observation is used by the author by making direct observations so that the author can find out how the subject sees the object under study. The result of this research is that the meaning received by adolescents in positive content is denotative meaning and the meaning that is received by adolescents in negative content is the connotative meaning and the reception of adolescents is included in the hegemonic - dominant position.
\end{abstract}

Keywords: Content Creator, Reception, TikTok

\begin{abstract}
Abstrak
TikTok merupakan aplikasi yang memberikan akses kepada penggunanya untuk membuat video berdurasi pendek dengan kreasi dan kreativitas yang dimiliki. Dalam aplikasi TikTok terdapat banyak sekali konten kreator yang membuat konten mulai dari konten positif hingga konten negatif. Penulis lebih memfokuskan kepada konten kreator@BotakTikTok karena konten kreator ini memiliki keunikan yaitu memiliki tiga akun TikTok. Tujuan penelitian ini adalah untuk mendeskripsikan resepsi remaja terhadap konten @BotakTikTok dalam media sosial. Metode penelitian yang digunakan dalam penelitian ini adalah metode pendekatan kualitatif dengan penelitian fenomenologi. Penelitian fenomenologi digunakan oleh penulis karena memungkinkan untuk mencari tahu dan memahami mengenai pemaknaan konten dalam media sosial (TikTok). Hasil data diperoleh melalui wawancara langsung dengan tiga narasumber, observasi langsung serta studi kepustakaan. Observasi digunakan oleh penulis dengan cara melakukan pengamatan langsung agar penulis bisa mengetahui cara pandang subjek terhadap objek yang diteliti. Hasil dari penelitian ini adalah makna yang diterima remaja dalam konten positif merupakan makna denotatif dan makna yang diterima remaja dalam konten negatif merupakan makna konotatif serta resepsi remaja termasuk kedalam posisi hegemonik-dominan.
\end{abstract}

Kata Kunci: Pencipta Konten, Resepsi, TikTok 
Steven Kesuma, H.H. Daniel Tamburian: Resepsi Remaja terhadap Konten @BotakTikTok di Media Sosial TikTok

\section{Pendahuluan}

Komunikasi merupakan hal yang sangat penting bagi kehidupan manusia terlebih jaman sekarang sudah mulai memasuki jaman modern dimana teknologi semakin canggih yang memudahkan manusia dalam berkomunikasi. Indonesia saat ini sedang terdampak pandemi covid19 atau virus corona yang memaksa masyarakat untuk melakukan segala sesuatu dirumah secara online. Media sosial merupakan salah satu alat komunikasi yang sering digunakan oleh masyarakat pada saat wabah virus corona. Salah satu media sosial yang sering digunakan adalah TikTok.

Menurut Artikel (Putra, 2018) TikTok merupakan aplikasi yang memberikan special effects unik dan menarik untuk membuat video pendek dengan kreasi dan kreativitas sesuai dengan keinginan penggunanya, berkomunikasi dengan pengguna lain melalui kolom komentar, ataupun memamerkan dan membagikan video hasil kreasi dan kreativitas kita ke teman, keluarga maupun pengguna lainnya. Special effects yang diberikan oleh aplikasi Tik Tok kepada penggunanya sangatlah banyak dan beraneka ragam sehingga akan membuat video - video pendek yang dihasilkan lebih bagus dan menarik serta efek - efek tersebut dapat digunakan secara instan, mudah, dan dapat digunakan berulang - ulang. Aplikasi TikTok ini juga memiliki varian musik yang beragam sehingga penggunanya dapat memilih lagu yang disuka saat ingin membuat video dengan melakukan tarian, gaya bebas, dan masih banyak lagi sehingga mendorong kreativitas penggunanya menjadi seorang konten kreator.

Di Indonesia sendiri, TikTok sempat ingin di blokir oleh pemerintah pada 2018 lantaran konten-kontennya. Namun, rencana tersebut dibatalkan. Pemerintah mengizinkan kembali TikTok beroperasi dengan syarat harus memberikan jaminan tidak akan menayangkan konten negatif seperti pornografi dan SARA. Sayangnya, di Indonesia, belum ada aturan jelas mengenai pengaturan dan pengawasan terhadap aplikasi media sosial. Karena itu, konten-konten bermuatan negatif masih kerap lolos dari pengawasan. (Rosmalia, 2020).

Dalam TikTok terdapat banyak sekali konten kreator yang membuat konten mulai dari konten positif dan menarik, menghibur, memberikan informasi dan tips serta ada juga konten yang negatif. Penulis lebih memfokuskan kepada konten kreator@BotakTikTok. Penulis memilih konten kreator@BotakTikTok karena @BotakTikTok sendiri merupakan konten kreator aktif dan memiliki 3 akun TikTok. Berdasarkan latar belakang tersebut, penulis memilih menganalisa pengguna media sosial TikTok karena ingin mengetahui bagaimana pemaknaan pada konten @BotakTikTok terutama dikalangan remaja. Peneliti ingin mengetahui bagaimana resepsi remaja terhadap konten@Botaktiktok dalam media sosial TikTok.

\section{Metode Penelitian}

Metode dalam penelitian ini adalah metode penelitian kualitatif dengan pendekatan fenomenologi. Metode penelitian ini digunakan karena penulis berupaya untuk mencari tahu makna atau dasar dari fenomena yang akan di teliti serta memungkinkan untuk mencari tahu dan memahami mengenai pemaknaan konten dalam media sosial TikTok. Penulis menggunakan teknik pengumpulan data melalui wawancara, observasi dan studi kepustakaan. Wawancara dilakukan secara langsung agar penelitian ini mendapatkan jawaban dan tanggapan langsung dari para narasumber serta penulis ingin melihat langsung gerak gerik tubuh para narasumber saat diwawancarai. Penulis mewawancarai remaja yang menggunakan aplikasi 
TikTok secara aktif dan berusia 19 - 23 tahun. Observasi dilakukan oleh penulis dengan pengamatan secara langsung. Observasi langsung merupakan salah satu teknik pengambilan data dengan menggunakan mata tanpa adanya bantuan alat lain (Nazir, 2011). Peneliti juga melakukan studi kepustakaan dengan mengumpulkan data referensi yang berasal dari buku - buku di perpustakaan hanya pada bagian yang penting saja (Nazir, 2011).

Langkah - langkah yang digunakan dalam mengolah data dan menganalisa data yaitu reduksi data, penyajian data dan penarikan kesimpulan atau verifikasi. Untuk menguji keabsahan datanya, penulis menggunakan teknik triangulasi. Triangulasi merupakan penggabungan teknik pengumpulan data dengan sumber data yang telah ada yang memiliki tujuan untuk mencari kebenaran tentang beberapa fenomena, tetapi pada tingkat pemahaman terhadap penelitian (Sugiyono, 2013).

\section{Hasil Temuan dan Diskusi}

Penulis mewawancarai pengguna TikTok di kalangan remaja mengenai tanggapan mereka terhadap konten - konten yang dibuat oleh konten kreator @BotakTikTok untuk mengetahui makna konotatif serta makna denotatif di nilai dari konten yang negatif sampai konten yang positif.

Menurut narasumber remaja yang menggunakan aplikasi TikTok, konten yang positif adalah konten yang menghibur, memotivasi dan menyadarkan seseorang sehingga melalui konten - konten tersebut para narasumber merasa terhibur dan dapat meningkatkan mood serta dapat termotivasi. Sedangkan menurut narasumber, konten yang negatif adalah konten - konten yang memberikan informasi agar jangan dilakukan tetapi kenyataannya konten kreator itu sendiri yang melakukan hal yang dilarang tersebut, konten - konten prank yang merugikan ataupun konten - konten negatif lainnya yang takutnya malah di ikuti oleh generasi jaman sekarang secara mentah - mentah.

Menurut Keraf (Sobur, 2011) makna pertama kali dibedakan atas makna konotatif dan makna denotatif. Kata yang tidak memiliki makna tambahan disebut makna denotatif, sedangkan kata yang memiliki makna tambahan disebut makna konotatif. Dari wawancara yang penulis lakukan, makna yang diterima oleh ketiga narasumber/informan mengenai konten positif yang ada di TikTok terutama konten kreator@BotakTikTok termasuk ke dalam kategori makna denotatif. Hal ini karena dari hasil yang didapat melalui wawancara dengan narasumber, penulis bisa menilai tafsiran mereka tentang bermanfaat atau tidaknya suatu konten di@BotakTikTok. Disisi lain, penulis menilai bahwa konten positif yang dibuat oleh konten kreator @BotakTikTok memiliki dampak positif bagi masyarakat yang melihat kontennya, sebaliknya jika@BotakTikTok membuat konten negatif akan memiliki dampak negatif juga. Hal tersebut menunjukkan tujuan dari TikTok sudah sejalan dengan tujuan pembuatan TikTok yaitu mendorong penggunanya untuk merekam dan menyajikan kreativitas melalui video pendek.

Selain mewawancarai ketiga informan/narasumber mengenai konten yang positif, penulis juga mewawancarai mengenai konten yang negatif. Dari hasil wawancara menunjukkan bahwa makna yang diterima oleh ketiga narasumber/informan mengenai konten negatif yang ada di TikTok terutama konten kreator@BotakTikTok termasuk ke dalam kategori makna konotatif. Hal ini karena dari hasil yang didapat melalui wawancara dengan informan/narasumber, penulis bisa menilai emosional informan mengenai konten kreator@BotakTikTok sehingga 
menurut ketiga narasumber konten negatif yang dibuat oleh konten kreator @ BotakTikTok tidak baik untuk dicontoh dan ditiru oleh pengguna lain yang menonton konten tersebut dan @BotakTikTok sendiri tidak boleh dijadikan panutan.

Terdapat tiga hipotesis yang dapat timbul di khalayak dalam memaknai isi pesan menurut Hall (2011) adalah Posisi yang dinegosiasikan (negotiated reading): khalayak di waktu tertentu menerima kode-kode program dan dasarnya sepaham dengan kode-kode yang diberikan si pembuat program tapi pada akhirnya menggantinya sampai sama seperti posisi yang diminati, lalu Posisi oposisional (Oppositional reading): khalayak tidak setuju dengan kode-kode program dan tidak menerima makna dari kode program tersebut dan akhirnya memilih pilihan lain dalam mengartikan makna kode program serta Posisi hegemonik-dominan (dominant-hegemonic reading): khalayak sepaham dengan kode-kode program (yang didalamnya terdapat nilai, sikap, keyakinan dan asumsi) dan menerima seluruh makna yang disampaikan dan diingini si pembuat program.

Tujuan dari pembuatan TikTok sendiri adalah mendorong penggunanya untuk merekam dan menyajikan kreativitas melalui video pendek. Walaupun terdapat konten negatif pada konten kreator@BotakTikTok, tetap saja tujuan dari TikTok sendiri sudah sejalan karena menebar hal positif dan@BotakTikTok sendiri lebih sering membuat konten yang menghibur. Berlandaskan analisis resepsi yang dikumpulkan oleh penulis terhadap konten@BotakTikTok, ketiga informan / narasumber remaja tersebut termasuk kedalam posisi hegemonik - dominan (dominant - hegemonic reading): khalayak sepaham dengan kode - kode program (yang didalamnya terdapat nilai, sikap, keyakinan dan asumsi) dan menerima seluruh makna yang disampaikan dan diingini si pembuat program. Ketiga informan / narasumber tersebut termasuk kategori ini dikarenakan mereka menerima konten konten yang disajikan oleh@BotakTikTok secara utuh dan menyeluruh tanpa sekalipun melaporkan konten - konten yang di buat@BotakTikTok. Hal ini sendiri dikarenakan Liandri, Dion dan Chandra menyukai konten kreator@BotakTikTok karena konten yang dibuat atau disajikan oleh konten kreator@BotakTikTok cenderung menghibur mereka.

\section{Simpulan}

Makna yang diterima oleh remaja terhadap konten positif termasuk kedalam kategori makna denotatif karena menyajikan konten yang bermanfaat. Sedangkan makna yang diterima oleh remaja mengenai konten negatif disebut sebagai makna konotatif karena para remaja menyarankan konten tersebut untuk tidak dicontoh atau ditiru oleh pengguna lain yang menonton konten.

Remaja dalam penelitian ini menilai akun media sosial TikTok @ BotakTikTok sendiri juga tidak boleh dijadikan panutan. Kendati demikian, resepsi remaja terhadap konten@BotakTikTok dalam media sosial berada pada posisi hegemonik - dominan karena menerima makna positif dari konten-konten yang dibuat oleh@BotakTikTok secara utuh dan menyeluruh, tanpa melaporkan konten-konten lain yang dibuat @BotakTikTok. Hal ini karena konten - konten yang dibuat dan disajikan oleh @BotakTikTok cenderung dimanfaatkan untuk menghibur. 


\section{Ucapan Terima Kasih}

Peneliti ingin menyampaikan terima kasih kepada seluruh pihak yang tidak dapat disebutkan satu persatu, yang telah membantu dan mendukung peneliti dalam penyusunan penelitian.

\section{Daftar Pustaka}

Hall, Stuart. (2011). The work of representation:"Representation: Cultural Representations and Signifying Practices (Culture,Media and Identities series). Ed Stuart Hall. USA: Sage Publication.

Nazir.Mohammad. (2011). Metode Penelitian. Jakarta : Ghalia Indonesia

Putra, Adhitya Wibawa. (2018). TikTok - sosial media berbasis video yang sedang sangat populer. Gadgettren.com. Diakses pada Maret 16, 2018. Terarsip di: https://gadgetren.com/2018/03/16/apa-itu-tik-tok-video-media-sosial/

Rosmalia, Putri. (2020). Sulitnya menghalau konten negatif di TikTok. Media Indonesia. Diakses pada September 19, 2020. Terarsip di: https://m.mediaindonesia.com/read/detail/346006-sulitnya-menghalaukonten-negatif-di-tiktok

Sobur, Alex. (2011). Analisis Teks Media. Bandung: PT Remaja Rosdakarya.

Sugiyono. (2013). Metode Penelitian Pendidikan Pendekatan Kuantitatif, Kualitatif, dan $R \& D$. Bandung: Alfabeta. 